\title{
Variation in the Origin of the Testicular Arteries and Drainage of the Right Testicular Vein
}

\author{
Variación en el Origen de las Arterias Testiculares y el Drenaje de la Vena Testicular Derecha
}

"Royana Singh; **Amit Jaiswal; *S. N. Shamal \& ${ }^{* * *}$ S. P. Singh

SINGH, R.; JAISWAL, A.; SHAMAL, S. N. \& SINGH, S. P. Variation in the origin of the testicular arteries and drainage of the right testicular vein. Int. J. Morphol., 29(2):614-616, 2011.

SUMMARY: During routine dissection of a 42 year old male Indian cadaver posterior abdominal wall, variations in the testicular vessels were observed. The right testicular artery arose from the right accessory renal artery, which originated from the ventral aspect of the abdominal aorta. The left testicular artery originated from the ventral aspect of the aorta in almost the same horizontal line as the right accessory renal artery, just below the superior mesenteric artery and $1.79 \mathrm{~cm}$, above the origin of the renal arteries. The right vein drained into the right accessory renal vein instead of the inferior vena cava, while the left testicular vein drained into the left renal vein. The presence of variation of both the testicular arteries as well as the testicular vein is seldom seen together.

KEY WORDS: Accessory Renal Artery; Renal artery; Renal vein; Testicular artery; Testicular Vein.

\section{INTRODUCTION}

The testicular arteries arise from the ventral aspect of the abdominal aorta below the renal artery at the level of the second lumbar vertebra. The right and left testicular veins which accompany the corresponding testicular artery drain in the inferior vena cava on the right and the left renal vein on the left side (Standring et al., 2005). Isolated description of the variation of the testicular arteries origin and variation of the testicular veins are found in the literature.

Variations in the origin of the artery have been observed by several authors since the beginning of the this century (Hollinshead, 1971; Onderog lu et al., 1993; Brohi et al., 2001). Similarly, the variations in the veins have been observed by (Asala et al., 2001; Xue et al., 2005; Yang et al., 2008). Variation of both the testicular artery as well as the testicular vein has been seldom mentioned together, more interest has been paid to the variations of the testicular artery than that of the testicular veins (Asala et al.). An attempt has been made in this case report to bring forth the existing variation of both the testicular arteries and the testicular veins along the possible embryogenesis leading to such variation. Furthermore, the knowledge of variations of the testicular vessels may be helpful to both the surgeons, clinicians as well as the radiologist dealing with operation and examination of the region or cases of sterility in male as a sequel to varicocele.

\section{MATERIAL AND METHOD}

During the routine dissection of 10 cadavers for the undergraduate classes, a 42 year old male cadaver of Indian origin, in the Department of Anatomy, Institute of Medical Sciences, Banaras Hindu University, exhibited two interesting variations of the testicular vessels. The testicular arteries possessed variation at their origin along with the variation in the drainage of the testicular veins.

\section{RESULTS}

The right testicular artery had its origin from the right accessory renal artery (Figs. 1A-E). The right accessory renal artery in turn had its origin from the ventral aspect of the aorta, $1.5 \mathrm{~cm}$ below the superior mesenteric artery, above the right renal artery. The right accessory renal artery ran a short oblique course behind the inferior vena cava, thereafter it ran anterior to the accessory renal vein, arching over it (Figs. 1D and 1E). At this point, the right testicular artery arose as a branch from right accessory renal artery to travel inferiorly along with the testicular vein to the right testis, while the right accessory renal artery passed posterior to the accessory renal vein to supply the lower pole of the kidney (Figs. 1D and 1E). The left testicular artery arose from the ventral aspect of the aorta, $1.0 \mathrm{~cm}$ below

\footnotetext{
* Department of Anatomy, Institute of Medical Sciences, Banaras Hindu University, Varanasi-221005, Uttar Pradesh, India.

** Internee, Institute of medical Sciences, Banaras Hindu University, Varanasi -221005, Uttar Pradesh, India.

**** Surgeon, Private Practitioner.
} 
superior mesenteric artery, a little above the left accessory renal artery almost in line with the right accessory renal artery. The left testicular artery, along with the left accessory renal artery arched over the left renal vessels to descend down obliquely along with the left testicular vein to the left testis (Figs. 1A-C). The left accessory renal artery arose from the ventro-lateral side of the aorta below the left renal artery, took a sinuous course over the ventral aspect of the renal vessels to reach the lower pole of the left kidney (Figs. 1A-C).
Testicular veins. The right testicular vein drained into the right accessory renal vein (Figs. 1A, 1D and 1E). The right testicular vein at its junction to the accessory renal vein arched over the proximal part of the accessory renal artery to drain into the inferior vena cava (Figs. 1D and 1E). The left testicular vein drained into the left renal vein close to the pedicle not at the point opposite to that left supra renal veins. Fig. 1C.
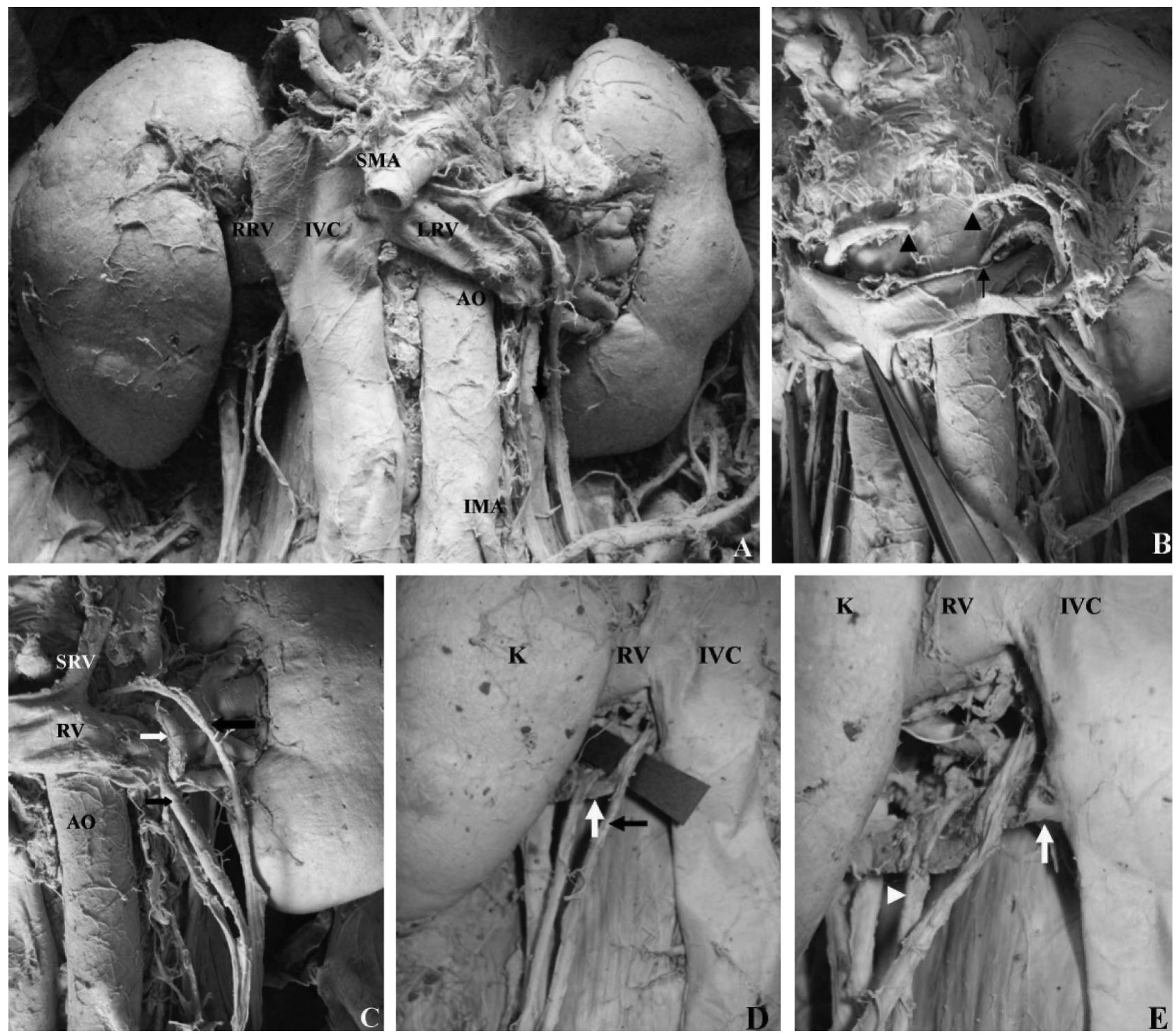

Fig. 1A. the gross photograph of the retroperitoneal space showing the two kidneys Aorta (AO), the left testicular and the left suprarenal veins draining into the left renal vein thereafter into the inferior vena cava (IVC) superior mesenteric artery (SMA), inferior mesenteric artery (IMA). B. The origin of the right accessory renal artery and the left testicular artery (arrow head, held by a forcep). The origin of left accessory renal artery, below the left testicular artery (arrow). C. The left renal vein (arrow black), the accessory left renal artery (white arrow), and the left testicular artery (black arrow bold). D. The right testicular artery (arrow black) as a branch from the left accessory renal artery (arrow white) arching over the accessory renal vein and present at a retrocaval position. E. The right testicular vein (arrow head white) draining into the right accessory renal vein draining (white arrow) into the inferior vena-cava. 


\section{DISCUSSION}

Variation of the testicular arteries are attributed to their embryonic origin from the lateral splanchnic arteries from the aorta. As the gonads descend new splanchnic arteries develop and the higher one atrophies (Moore \& Persaud, 1993). In this case, we assume that the higher arteries might have persisted, thus resulting in higher origin from the aorta and arching over the left renal vessels. Similar arching of the left testicular artery was observed (Lelli et al., 2007; Acar et al., 2007), but its origin from aorta was below the renal arteries. On the right side, the higher splanchnic artery to the right side testis may have persisted and on its way gave origin to an accessory renal artery to supply the lower pole of the right kidney.

The retro caval portion of the accessory right renal artery can be explained as, the renal segment of the inferior vena cava develops from the three venous channels: supra cardinal, subcardinal and posterior cardinal. When the lateral splanchnic artery passes cranial to renal segment it becomes retro caval (Standring et al.).

The testicular vessels which may arch over the renal vessels, as in this case, form a component of the renal pedicle. Therefore, it should be borne in mind of the surgeons dealing with operations of this region. Furthermore, the accessory renal artery arching over the testicular vein may lead to varicocele (ovarian varicocele in females) and sterility in males as its sequel (Asala et al.) or may be a cause of orthostatic albuminuria (Lelli et al.). Thus, variations of the testicular arteries and the testicular veins should be borne in mind of the clinicians, surgeons and radiologist while dealing with this region.

SINGH, R.; JAISWAL, A.; SHAMAL, S. N. \& SINGH, S. P. Variación en el origen de las arterias testiculares y el drenaje de la vena testicular derecha. Int. J. Morphol., 29(2):614-616, 2011.

RESUMEN: Durante una disección de rutina de un cadáver, perteneciente a un hombre indio de 42 años, se observaron variaciones en los vasos testiculares en la pared abdominal posterior. La arteria testicular derecha se originó desde la arteria renal accesoria, proveniente de la cara ventral de la parte abdominal de la aorta. La arteria testicular izquierda se originó en la cara ventral de la parte abdominal de la aorta, casi en la misma línea horizontal de la arteria renal accesoria derecha, justo distal a la arteria mesentérica superior y $1,79 \mathrm{~cm}$ sobre el origen de las arterias renales. La vena renal derecha drenaba en la vena renal accesoria en lugar de la vena cava inferior, mientras que la vena testicular izquierda drenaba en la vena renal izquierda. En muy pocas ocasiones es posible observar de manera conjunta, variaciones tanto de las arterias como de las venas testiculares.

PALABRAS CLAVE: Arteria renal accesoria; Arteria renal; Vena renal; Arteria testicular; Vena testicular.

\section{REFERENCES}

Acar, H. I.; Yazar, F. \& Ozan, H. Unusual origin and course of the testicular arteries. Surg. Radiol. Anat., 29(7):601-3, 2007.

Asala, S.; Chaudhary, S. C.; Masumbuko-Kahamba, N. \& Bidmos, M. Anatomical variations in the human testicular blood vessels. Ann. Anat., 183(6):545-9, 2001.

Brohi, R. A.; Sargon, M. F. \& Yener, N. High origin and unusual suprarenal branch of a testicular artery. Surg. Radiol. Anat., 23(3):207-8, 2001.

Hollinshead, W. H. Anatomy for surgeons. $2^{\text {nd }}$ edn. New York, Harper \& Row, 1971. pp.579-80.

Lelli, F.; Maurelli, V.; Maranillo, E. \& Valderrama-Canales, F. J. Arched and retrocaval testicular arteries: a case report. Eur. J. Anat., 11(2):119-22, 2007.

Moore, K. L. \& Persaud, T. V. N. The urogenital system. In: Moore, K. L. \& Persaud, T. V. N. (Eds). The Developing Human. 5th edn. Philadelphia, WB Saunders, 1993. pp.265-303.
Onderog \lu, S.; Yüksel, M. \& Arik, Z. Unusual branching and course of the testicular artery. Ann. Anat., 175(6):541-4, 1993.

Standring, S.; Ellis, H.; Healy, J. C.; Johnson, D. \& Williams, A. Gray's Anatomy. $39^{\text {th }}$ ed. Edinburgh, Elsevier Churchill Livingston, 2005. pp.1274.

Xue, H. G.; Yang, C. Y.; Ishida, S.; Ishizaka, K.; Ishihara, A.; Ishida, A. \& Tanuma, K. Duplicate testicular veins accompanied by anomalies of the testicular arteries. Ann. Anat., 187(4):393-8, 2005.

Yang, C. Y.; Xue, H. G.; Tanuma, K. \& Ozawa, H.Variations of the bilateral testicular veins: embryological and clinical considerations. Surg. Radiol. Anat., 30(1):53-5, 2008.

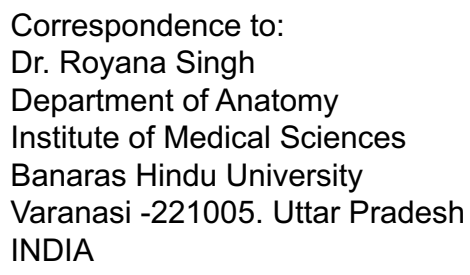

Email: singhroyana@rediffmail.com
Accepted: 14-03-2011
Received: 05-02-2010 